\title{
Interest Rate Transmission Effect on Money Supply: The Nigerian Experience
}

\author{
Ebiringa, Oforegbunam Thaddeus (Ph. D) \\ Department of Management Technology, Federal University of Technology, Owerri-Nigeria \\ otebiringa@yahoo.com
}

Received: February 21, 2012 Accepted: April 13, 2012 DOI: 10.5296/jpag.v2i1.1683

\begin{abstract}
This paper investigates the effect of interest indices on money supply. The motivation is to ensure stability in money supply through sustainable interest rate management. The period 1990-2007 was covered. The Eviews software was used to carry out autoregressive analysis on the variable as well as an assessment of the effects on interest rate indices on money supply. The results among others show that minimum rediscount rate and savings rate have made significant positive impact on money supply. On the other hand, lending rate has made insignificant negative impact on money supply. Based on the above results the conclusion of the study the inability of the monetary authority to narrow the gap between saving and lending rate remains a key to the problem of instability in money supply, hence concerted effort must by made to strengthen the capacity of regulatory authorities to use market based options monitor and control periodic volatility in money supply through an effective interest rate regimes.
\end{abstract}

Key words: Money, Interest rate, volatility, endogenous, spread, integration, intermediation 


\section{Introduction}

Variability of interest rate structure is a prominent feature of market based economy. Interest rates change in response to a variety of domestic and international economic events. The term cyclical volatility of interest rates refers to the variability of interest rates over periods that correspond to the length of the typical business cycle (Chong et al, 2006). Variability of interest rates affects decisions about how to save and invest. Nigeria experienced severe macroeconomic problems towards the end of 1970s through the first half of the 1980s when output declined substantially. The real GDP growth rate averaged only $1.5 \%$ per annum during the period 1973-1980 (registering negative growth rate in 6 years during the period) (Teriba, 2006). In response to this deteriorating economic situation, the Nigerian authorities launched policy programmes contained in the Structural Adjustment Programme (SAP). Several forms of corrective measures were undertaken including financial sector reform policies. The interest rate policy in Nigeria is perhaps one of the most controversial of all financial policies. The reason for this may not be farfetched because interest rate policy has direct bearing on many other economic variables such as investment decision. Interest rates play a crucial role in the efficient allocation of resources aimed at facilitating growth and development of an economy and as a demand management technique for achieving both internal and external balance with specific attention for deposit mobilization and credit creation for enhanced economic development (De Angelis et al, 2005). The central objective of this study is to examine effect of interest rate on money supply in Nigeria with specific attention on the short and long run effects of minimum rediscount rate, commercial bank lending and savings rates.

\section{Theoretical Framework}

Market interest rate adjustment otherwise known as stickiness is used to describe the responsiveness of market interest rates to changes in another interest rate, such as the policy interest rate. The level of stickiness is measured by how small the change in the official interest rate elicits a change in the market interest rates. Aziakpono and Wilson (2007) stated that the literature also differentiates between adjustment in the short-run and in the long-run. While there may be a considerable degree of response of market interest rates (complete; incomplete) to changes in the official interest rate in the long-run, the short-run may be different. Because of costs of adjustment, banks may respond sluggishly to changes in the official rate in the short-run. The short-run sluggishness may be intensified by characteristics of poor or limited alternative financing or investment sources to bank loans or deposits. As a result banks may not feel pressured to adjust their rates in the short-run when the official rate changes. Lastly, due to long-term relationships with their customers, banks may want to smooth interest rates changes thereby creating a gap between the long-run and short-run adjustment (Egert, et al. 2007). A wide gap between the short-run and the long-run adjustments can also be viewed as evidence of interest rate rigidity.

From another perspective, the central banks' operations is aimed to influence the overall lending policies of banks, the demand for money and credit in the economy through changes 
in bank liquidity and interest rates in the money market. As such much of the theoretical literature about interest rate adjustment tends to focus on short-term money market interest rates, especially the various deposit and lending rates of banks. Changes in interest rates in the money markets should then be translated into long-term capital market interest rates as suggested by the expectations theory of the yield curve. But as indicated by the liquidity preference theory of the yield curve, due to risks in long-term debts, the long-term interest rates will not reflect perfectly the changes in the short-term rates. Hence, for developed financial system, the expectation is adjustments in the long-term interest rates should be lower than in the short-term money market interest rates in response to changes in the official interest rate (De Graeve et al, 2007) . This means the situation may be different where the capital market is not developed with the banking system dominating the financial system.

\subsection{Factors affecting interest rates}

Theoretically, a number of factors may affect the adjustment of interest rates. These include: monetary policy orientation- liberal or control regime; financial structure - its development level, banking sector concentration, bank size, the degree of openness of the financial market; asymmetric information; and menu costs amongst other things (Gambacorta, 2008).

Monetary policies under controlled interest rates and credit allocation are inherently rigid, since changes in interest rates are not as a result of markets' spontaneous adjustments. In contrast, a deregulated environment allows the market to determine interest rates and credit allocation. In such an environment, market rates are more flexible and do readily adjust to changes in monetary policy stance (Aydin, 2007).

The structure of the financial system also affects how interest rates adjust. It is part of financial structure the degree of competition within the banking system, competition between banks and other non-bank intermediaries. What sets the level of competition in financial system is the regulatory environment, the number and size of intermediaries, the ownership structure as well as the openness of the financial system. Profit-maximizing behaviour in a competitive market, induce banks to adjust their rates promptly to changes in the market conditions. Conversely if market forces are weak, inefficiency will not be penalised and bank interest rates may be more rigid (Hofmann, 2006).

Also, in a highly oligopolistic (concentrated) banking market, banks may cause interest rates to adjust asymmetrically to an increase or a decrease in the official rate. The asymmetric adjustment of interest rates can be explained using two competing hypotheses (Huslsewig, et al, 2009) . Firstly the collusive behaviour hypothesis which suggests that deposit rates will be rigid upward when the official rate is increased, while the lending rates will be rigid downward in the case of a decrease in the official rate. Secondly, the adverse customer reaction hypothesis which suggests that deposit rates will be rigid downward when the official rate is decreased, while the lending rates will be rigid upward in the case of an increase in the official rate (De Bondt, 2005). 


\section{MInstitute ${ }_{\text {Mnk }}^{\text {Macrothin }}$}

The ownership structure of banks (that is whether state-owned or private sector owned) is another factor that could influence the speed of adjustment of interest rates. State domination of banking system results in banking concentration or some form of monopoly, which may cause inefficiency hence rigidity in the interest rates.

The response of domestic banks to changes in the official rate also depend on the extent to which banks rely on the accommodation facilities provided by the central bank for their liquidity needs (Burgstaller, 2003). If the financial system is sufficiently open and banks can easily access external source of finance, this may reduce banks reliance on the accommodation facilities from the central bank (Baugnet, et al. 2007). Consequently, in an open financial system the response of bank interest rates to changes in the official rate may be slower than when the market is not open.

Chionis and Leon (2006) provide another explanation for interest rate rigidity based on asymmetric information. If banks perceive the risk of default to be very high, they will maintain a large spread between lending and deposit rates. If this cushion is very large, then market lending rate may be relatively insensitive to small changes in official rate.

Lastly, the level of development of the financial system affects the degree of interest rate adjustment. A well developed financial system will offer alternative financial instruments and intermediaries for investors and savers thereby providing alternative investment or financing sources to bank loans and deposits. In addition to the availability of other financial intermediaries, alternative financing or investment sources include active and broad markets for Treasury bills, long-term bonds (both government and private), and an active stock market. In such a developed financial system, no single financial intermediary enjoys absolute market power and interest rates are more flexible in responding to changes in market conditions (Kaketsis and Sarantis, 2006).

The foregoing discussion shows that several factors - which vary from country to country could cause the stickiness of market interest rates. Moreover, stickiness will vary within a country as the financial environment changes over time. These variations are critical to the calibration and execution of monetary policy (Kwapil and Scharler, 2009) . Little wonder, therefore, that, the relationship between official interest rates and market interest rates has given rise to growing empirical literature.

\section{Methodology}

This study is design to be deterministic as it employed econometric models using time series data for its analysis. With the aim of examining interest rate variation and its impact on money supply, annual series data from 1990-2009 as it relates to savings and deposit rates and minimum rediscount rate was used as explanatory variables. Following the lead of Khan (1997), the study employs two econometric models to achieve results.

The primary model showing the relationship between money supply stability and interest rate 


\section{IIMacrothink}

indices as used by Jankee (2004) is specified thus:

$$
\mathrm{Y}_{\mathrm{it}}=\alpha_{0}+\alpha_{1} \mathrm{I}_{\mathrm{t}}+\mathrm{Q}_{0}
$$

The first step involves testing the order of integration of the individual series under consideration. The Augmented Dickey-Fuller (ADF) test, which relies on rejecting a null hypothesis of unit root (the series are non-stationary) in favour of the alternative hypotheses of stationarity of series (Rapach and Weber, 2004). The tests are conducted with and without a deterministic trend $(t)$ for each of the series. The general form of ADF test is estimated by the following regression

$$
\Delta y_{t}=a_{0}+\alpha_{1} y_{t i-1}+\sum_{n=1}^{n} \alpha_{1} \Delta y_{i}+\delta_{t}+e_{t}
$$

Where y stands for money supply and I are interest rate proxies.

Annual time series data for the period between 1990 and 2007 were. Table 4.2 reports the unit root test results using Augmented Dickey Fuller (ADF) test.

The multiple regression model was used to test the effect of the interest rate proxies on money supply using the function

$\mathrm{Y}=\mathrm{a}_{0}+\mathrm{b}_{1} \mathrm{X}_{1}+\mathrm{b}_{2} \mathrm{X}_{2}+\mathrm{b}_{3} \mathrm{X}_{3}+\mathrm{e}_{0} \quad \ldots \quad$ 3.3.

Where $X_{1}, X_{2} \ldots X_{n}$ are the time series of interest rate proxies

$\mathrm{Y}=$ the time series of money supply.

The testing of the significance of the effect model in this study was undertaken with the help of the Analysis of Variance. 


\section{Macrothink}

\section{Results and Discussions}

Table 4.1: Macroeconomic Aggregates

\begin{tabular}{|c|c|c|c|c|}
\hline Year & $\mathbf{Y}$ & $\overline{X_{1}}$ & $\mathbf{X}_{2}$ & $\mathbf{X}_{\mathbf{3}}$ \\
\hline 1990 & 8662.5 & 18.50 & 25.50 & 18.80 \\
\hline 1991 & 7499.8 & 14.50 & 20.01 & 14.29 \\
\hline 1992 & 129085.5 & 17.50 & 29.80 & 16.10 \\
\hline 1993 & 198479.2 & 26.00 & 18.32 & 16.66 \\
\hline 1994 & 266944.9 & 13.50 & 21.00 & 13.50 \\
\hline 1995 & 318763.5 & 13.50 & 20.18 & 12.61 \\
\hline 1996 & 370333.5 & 13.50 & 19.74 & 11.69 \\
\hline 1997 & 429731.3 & 13.50 & 13.54 & 4.80 \\
\hline 1998 & 525637.8 & 14.31 & 18.29 & 5.49 \\
\hline 1999 & 699733.7 & 18.00 & 21.32 & 5.33 \\
\hline 2000 & 1036079.5 & 13.50 & 17.98 & 5.29 \\
\hline 2001 & 1315869.1 & 14.31 & 18.29 & 5.49 \\
\hline 2002 & 1599494.6 & 19.00 & 24.85 & 4.15 \\
\hline 2003 & 1985191.8 & 15.75 & 20.71 & 4.11 \\
\hline 2004 & 2263587.9 & 15.00 & 19.18 & 4.19 \\
\hline 2005 & 2814846.1 & 13.00 & 17.95 & 3.83 \\
\hline 2006 & 4027901.7 & 12.25 & 17.26 & 3.14 \\
\hline 2007 & 5809826.5 & 8.75 & 16.94 & 3.55 \\
\hline 2008 & 9166835.3 & 9.81 & 15.14 & 2.84 \\
\hline 2009 & 10767377.8 & 7.44 & 18.36 & 2.94 \\
\hline \multicolumn{5}{|c|}{$\begin{array}{l}Y=\text { Money Supply } \\
X_{1}=\text { Minimum Rediscount Rate } \\
X_{2}=\text { Prime lending Rate } \\
X_{3}=\text { Savings Rate }\end{array}$} \\
\hline
\end{tabular}

Table 4.2: Summary of Dickey-Fuller Unit Root Test on Variables

\begin{tabular}{|l|l|l|l|l|l|}
\hline variables & $\begin{array}{l}\text { ADF Test } \\
\text { Statistic }\end{array}$ & $\begin{array}{l}\mathbf{1 \%} \\
\text { Critical } \\
\text { Value }\end{array}$ & $\begin{array}{l}\mathbf{5 \%} \\
\text { Critical } \\
\text { Value }\end{array}$ & $\begin{array}{l}\mathbf{1 0 \%} \\
\text { Critical Value }\end{array}$ & Decision \\
\hline Y & 2.553394 & $-3.8572^{*}$ & $-3.0400^{*}$ & $-2.6608^{*}$ & Not sig. at level \\
\hline X1 & -1.486201 & $-3.8572^{*}$ & $-3.0400^{*}$ & $-2.6608^{*}$ & Not sig. at level \\
\hline $\mathbf{X 2}$ & -1.961345 & $-3.8572^{*}$ & $-3.0400^{*}$ & $-2.6608^{*}$ & Not sig. at level \\
\hline $\mathbf{X 3}$ & -1.231816 & $-3.8572^{*}$ & $-3.0400^{*}$ & $-2.6608^{*}$ & Not sig. at level \\
\hline
\end{tabular}

*MacKinnon critical values for rejection of hypothesis of a unit root. 


\section{$\triangle$ Macrothink}

Table 4.2 shows that the Augmented Dickey-Fuller Unit root test statistics are all lower than the critical values at $1 \%, 5 \%$ and $10 \%$ at level. The conclusion therefore is that each variable distribution is not serially correlated (stationary).

\subsection{Effect of Interest Rate Proxies on Money Supply}

\section{Table 4.3: Summary of Output}

Dependent Variable: Y

Method: Least Squares

Included observations: 20 after adjusting endpoints

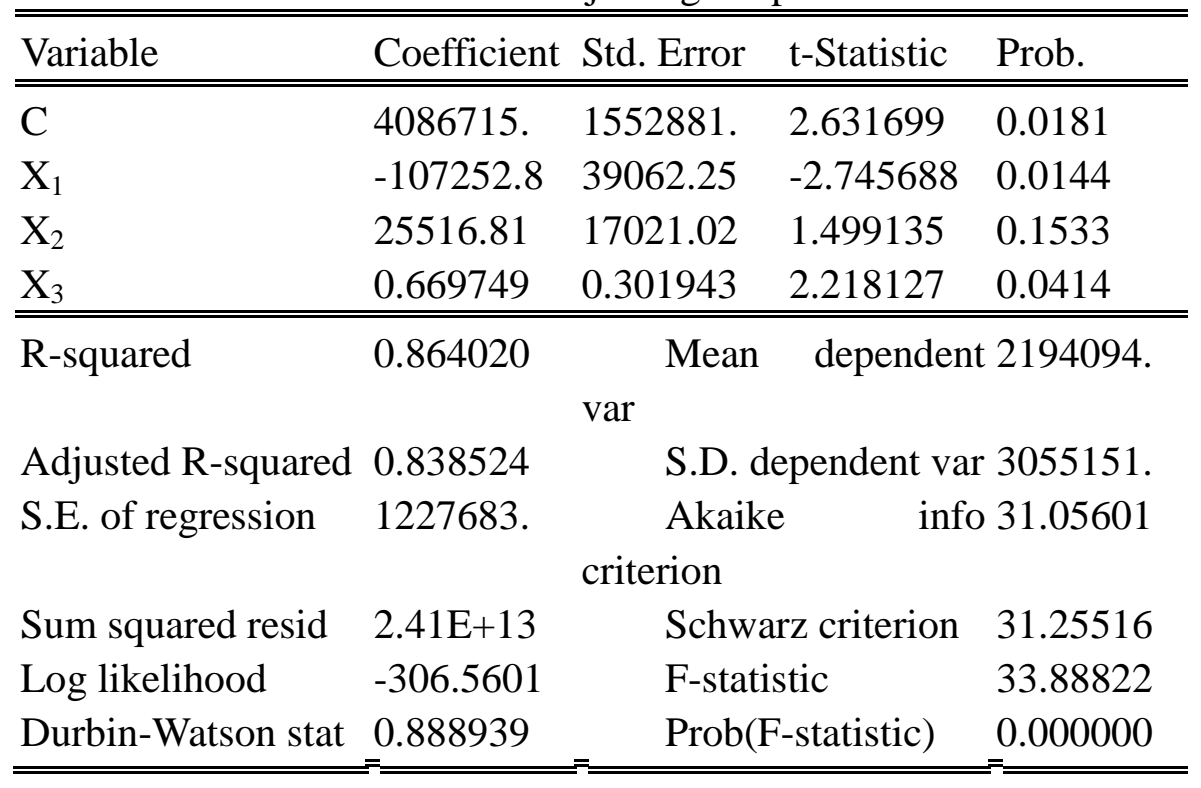

Effect Model: $\quad \mathrm{Y}=4086715-107252.8 \mathrm{X}_{1}+25516.81 \mathrm{X}_{2}+0.67 \mathrm{X}_{3} \quad \ldots 4.1$
$(-2.746)$
$(1.499)$

Equation 4.1 shows that $\mathrm{X}_{1}$ (Minimum rediscount rate) is inversely related to $\mathrm{Y}$ (Money Supply), while on the other hand $\mathrm{X}_{2}$ (Prime lending rate) and $\mathrm{X}_{3}$ are positively related to $\mathrm{Y}$. The $t$ values calculated for the explanatory variables shows that $X_{1}(-2.746)$ and $X_{3}(2.218)$ exhibited significant negative and positive effects on money supply at 0.05 level respectively, while $\mathrm{X}_{2}$ (1.499) exhibits positive effect though not significant. The joint effect of variations of the three proxies of interest rate $\left(\mathrm{X}_{1}, \mathrm{X}_{2}\right.$ and $\left.\mathrm{X}_{3}\right)$ on changes in $\mathrm{Y}$ (Money Supply) is 86.40 percent (see shows the $\mathrm{R}$ squared $=0.864020$ ). The Fcal. value of 33.89 which is significant at 0.001 level confirms that equation 4.1 is a reliable model for predicting the significance of the effect of interest rate proxies on money supply in Nigeria. The Durbin-Watson statistic of 0.89 which is less than 2 for order one attest to the fact that the error margin in predicting annual money supply observations using equation 4.1 is not significant. We therefore reject the null hypothesis and conclude that there exists sufficient 
empirical evidence to suggest that volatility in interest rate proxies is only significantly responsible for short run variation in money supply in Nigeria.

\section{Conclusions}

Based on the results obtained the following conclusions are made:

$>$ Minimum rediscount rate (Monetary Policy Rate -MPR) as a monetary policy instrument has significantly been used by the regulatory authorities in Nigeria as a short run measure to moderate volatility in money supply as equation 4.1 lacks autoregressive input of $\mathrm{X}_{1}$.

$>$ Volatility in commercial bank lending rate is not significantly responsible for periodic variation in money supply in Nigeria. This is based on the tcal value of $\mathrm{X}_{2}$ which is not significant at 0.05 level as shown on Table 4.2. The direct relationship between $\mathrm{Y}$ and $\mathrm{X}_{2}$ as shown in equation 4.1 imply that increasing commercial banks' lending rate has led to short run increase in money supply, though not significant. This effect is not consistent with the expected. The likely reason being the inadequate integration of the banking system with the real sector, which leads to delay transmission of effect of banking activities to the entire economy.

$>$ Volatility in commercial bank savings rate is significantly responsible for periodic variation in money supply index in Nigeria. This is based on the tcal value of $\mathrm{X}_{3}$ which is significant at 0.05 level as shown on Table 4.2.

The sign of $\mathrm{X}_{1}$ as shown in equation 4.1 is consistent with already established theories, which confirms that the Central Bank of Nigeria uses minimum rediscount rate as indirect monetary policy instrument to control short run movements in money supply simply by either constraining or expanding the ability of banks to grant credits. On the other hand, the extent to which $\mathrm{X}_{2}$ (Prime lending rate) and $\mathrm{X}_{3}$ (deposit rate) can be used to control money supply (Y) is mixed as it depends on other intervening socioeconomic variables.

\section{References}

Aydin, H. I. (2007) "Interest rate pass-through in Turkey", Research and Monetary Policy Department Working Paper No 07/05, Ankara: The Central Bank of the Republic of Turkey.

Aziakpono, M. J., M. Wilson and J. Manual, (2007) “Adjustment of Commercial Banks' Interest Rates and the Effectiveness of Monetary Policy in South Africa", African Finance Journal, 9(1):1-20.

Baugnet, V., M. Collin and E. Dhyne (2007) "Monetary policy and the adjustment of the Belgian private bank interest rates- an econometric analysis", National Bank of Belgium Research Department.

Burgstaller, J. (2003) "Interest Rate Transmission to Commercial Credit Rates in Austria", 
Working Paper No.0306, John Kepler University of Linz, Austria.

Chionis, D. P. and C. A. Leon (2006) "Interest rate transmission in Greece: did EMU cause a structural break?”, Journal of Policy Modeling, 28:453-466.

Chong, B. S., M-H. Liu and K. Shrestha (2006) "Monetary transmission via the administered interest rates channel", Journal of Banking and Finance, 30:1467-1484.

De Angelis, C., M.J. Aziakpono and A. P. Faure (2005) "The transmission of monetary policy under the repo system in South Africa: an empirical analysis", South African Journal Economics, 73(4): 657-673.

De Bondt, G.J (2005) "Interest rate pass-through: empirical results for the Euro Area", GermanyEconomic Review, 6(1): 37-78.

De Graeve, F., O. De Jonghe and R. V. Vennet (2007) "Competition, transmission and bank pricing policies: evidence from Belgian loan and deposit markets", Journal of Banking and Finance, 31:259-278.

Egert, B., J. Crespo-Cuaresma and T. Reininger (2007) "Interest rate pass-through in central and Eastern Europe: Reborn from ashes merely to pass away?", Journal of Policy Modeling, 29:209-225.

Gambacorta, L. (2008) "How do banks set interest rates", European Economic Review, 52:792-819.

Hofmann, B. (2006) "EMU and the transmission of monetary policy: evidence from business lending rates", Empirica, 33:209-229.

Huslsewig, O., E. Mayer and T. Wollmershauser (2009) "Bank behaviour, incomplete interest rate pass-through, and the cost channel of monetary policy transmission", Economic Modelling, 26:1310-1327.

Jankee, K. (2004), "Testing for Nonlinearities in the Adjustments of Commercial Banks' Retail Rates to Interbank Rates: The Case of Mauritius", Paper presented.

Kaketsis, A. and N. Sarantis (2006) "The Effects of Monetary Policy Changes on Market Interest Rates in Greece: An event Study Approach", International Review of Economics and Finance, 15:487-504.

Khan, A. H., and S. S. Ali (1997) "The Demand for Money in Pakistan: An Application of Cointegration and Error-Correction Modeling", Saving and Development, 21(1): 48-61.

Kwapil, C. and J. Scharler (2009) "Interest rate pass-through, monetary policy rules and macroeconomic stability", Journal of International Money and Finance, 
Doi:10.1016/j.jimonfin.2009.06.010.

Rapach, D. E. and C. E. Weber (2004) “Are Real Interest Rates really Nonstationary? New Evidence from tests with Good Size and Power", Journal of Macroeconomics, 26: 409-430.

Teriba A.O. (2006) "Information Content of Interest Rates Spreads In Nigeria" African Economic Research Consortium (Aerc), Paper Series 